\title{
The Future of the University: A Contingency Analysis of Professors' Perspectives ${ }^{\dagger}$
}

\section{MANUEL CRESPO* and DORIS ACEVEDO**}

\begin{abstract}
Within the framework of contingency theory, the impact of environmental and organizational variables on professors' perspectives on the future of the university is analyzed. The sample consists of 1225 university professors of all Québec universities who answered a survey questionnaire in the fall of 1984 and the winter of 1985 . More than two thirds of respondents $(76,2 \%)$ advocate a greater selectivity in university admissions. A majority $(55,4 \%)$ agree with a market orientation of universities. Approximately $90 \%$ are in favour of the search for non-governmental funds. Almost two thirds $(63,7 \%)$ think that less viable departments should be protected. A strong majority (80,7\%) support a closing of the technological gap of Québec society. Finally, $80 \%$ favour greater university autonomy. Regression analyses show that area of specialization of department is related to all future issues, while language of department is related to four of them. Organizational variables, particularly decline, did not prove to be decisive factors in determining professors' perspectives. With the exception of sex, control variables were not consistently related to future issues.
\end{abstract}

$\dagger$ Revised version of a paper presented at the Annual Meeting of the American Educational Research Association, San Francisco, March 27-31, 1989. The authors thank Raymond Fournier, Faculty of Education, Université de Montréal, for his assistance in data analysis. The authors also thank Darell Lewis of the University of Minnesota and Clement Dassa of the Université de Montréal for their most valuable comments. Comments and suggestions by two anonymous reviewers were very helpful in revising the paper. All inaccuracies are, however, the authors' sole responsibility. This research was jointly funded by the Formation de chercheurs et aide à la recherche (Government of Québec) and by the Social Sciences and Humanities Research Council (Government of Canada).

*Faculté des sciences de l'éducation, Université de Montréal, Canada

**Universidad de Carabobo, Venezuela 
Since explained variances are low, further research is needed to more adequately account for professors' perspectives.

\section{Résumé}

Dans cet article, les auteurs analysent, à partir de la théorie de la contingence, quelles pourraient être les conséquences de changements d'organisation et d'environnement sur les perspectives des professeurs sur l'université de demain. L'échantillon se compose de 1225 professeurs d'universités, enseignant dans des établissements situés au Québec et qui ont répondu au sondage réalisé en automne 1984-hiver 1985. Plus des deux tiers des répondants, soit 76,2\%, sont partisans d'une plus grande sélection des étudiants avant leur entrée à l'université. La majorité $(55,4 \%)$ croit qu'une considération plus poussée des tendances du marché du travail au sein des universités est une bonne chose et 90 \% souhaitent que le financement des universités soit constitué pour une plus grande part de fonds privés. Presque les deux tiers $(63,7 \%)$ pensent qu'il faut protéger les secteurs moins rentables et une large majorité $(80,7 \%)$ souhaite que le Québec mette fin à son retard technologique. Enfin, $80 \%$ des professeurs se disent en faveur d'une plus grande autonomie des universités. Les analyses de régression montrent que le domaine de spécialisation des différents secteurs se trouve au coeur de tous ces enjeux futurs tandis que la langue parlée à l'université en touche quatre. Les variables liées à l'organisation, notamment la décroissance n'ont pas semblé jouer un rôle décisif pour déterminer les perspectives d'avenir des professeurs. Les variables de contrôle, à l'exception de celle relative au sexe, n'etaient pas reliées de manière significetive aux perspectives des professeurs. Comme les variances expliquées sont faibles, d'autres recherches devront être entreprises afin de donner une idée plus juste des perspectives d'avenir des professeurs d'université.

During the past fifteen years, systems of higher education in developed countries have been struggling with budgetary cuts that have forced local administrations to adopt, in many cases, compensatory short-term strategies (Crespo, 1990; Jackson, 1979; Hardy, 1984; Shore, 1985; Shattock and Berdhal, 1984; Scheidt, 1979; Volkwein, 1984). Few studies report cases of institutions that have taken into consideration long term effects of the management of austerity (see, for example, Smith, 1986; Pennsylvania State University, 1980). 
These strategies have been reported to have, in turn, several dysfunctional consequences. According to Cameron, Kim and Whetten (1987): "writers generally have agreed that in conditions of organizational decline, conflict, secrecy, rigidity, centralization, formalization, scapegoating, and conservation increase. Morale, innovativeness, participation leader influence, and long term planning decrease" (p. 225) (see also, Cameron, Whetten \& Kim, 1987). The management of austerity also has propelled to the forefront some issues related to the future of the University. This paper deals with some of these issues from the perspectives of university professors in Quebec.

Several themes emerge from the literature on the future of the University, including the following: 1) the questions of selectivity, equality and excellence; 2) the question of market orientation and 3) the question of university autonomy. A recent OECD Report (1987) discussed these issues in a broad manner; other reports and scholarly papers have also addressed these issues in different national contexts.

The questions of equality and excellence are prominent in the contemporary debate on higher education throughout Europe and North America (National Institute of Education, 1984; Astin, 1985; Fulton, 1988; Trow, 1987; Volkwein, 1986; Lesourne, 1989). When university funding is heavily dependent on numbers of students, pressures build up to enhance open-door policies. In cases, however, where the higher education systems are overcrowded, as in France and West Germany, and where student enrolment is not as determinant of budget allocation as it may be in Canada or the United States, governments and university administrations may wish to resort to stricter rules of admission.

Systems are also forced to become more accountable because of reduced resources. A policy of quality and excellence may be, as it seems to be in England, an alternative for improving effectiveness (Moodie, 1988, see also, Sizer, 1988). Equality and excellence could probably not be pursued at the same time, and the question may be that of knowing how far an institution can go to meet equality demands without endangering the quality of the product.

The question of market orientation within academe has bearings on programming and relations with the private sector (see Lesourne, 1989). Higher education institutions may be inclined to scale down departments with lesser market value and divert financial and human resources towards demand sectors (Halls, 1985). Also, given the contraction of public financial resources, universities have progressively involved themselves in projects with the industrial sector. 
The mechanisms of cooperation between university and industry take several forms: science parks, intermediary bodies, industrial liaison offices, teaching companies and industrial companies (Cerych, 1985). Dozens of articles have treated this topic within the North American context (Muller and Sepehri, 1988; Levin and Sullivan, 1988; Leclerq, 1988; Bélanger, 1988; Forum entreprises-universités, 1984; 1985; 1987; Laplante, 1988; Powers \& Powers, 1988; Varrin \& Kubich, 1985; Stankiewicz, 1986; Conseil des sciences du Canada, 1988; Miller \& Côté, 1987; recent issues of Journal of Research Administrators). The topic has also been treated within other contexts, albeit to a lesser extent (Ashworth, 1985; McKinnon, 1988; Theis, Groumann \& Oppermann, 1986; OECD, 1984; Avveduto, 1988; Wasser, 1989).

Finally, the theme of university automony is also prominent in public debate and scholarly work. The dependence on public funding is conducive to university forced alignment with governmental priorities in higher education (Slaughter, 1988). University-industry relations also pose the problem of institutional autonomy and freedom of research. Paradoxically, universities seek to develop relationships with the industrial sector to enhance their autonomy vis-à-vis governmental control (Berchem, 1985).

How do university professors perceive the future of the University? Which factors influence their perspectives? Professors play a significant role in loosely-coupled institutions that characterize universities (March \& Olsen, 1975; Salancik, 1975; Weick, 1976). In the traditional European model of academic organization, chaired professors are key actors in the local decision-making process even if a large measure of centralization exists at the state level (Clark, 1977; see also Clark, 1983). New trends in European governance of higher education tend to confirm this traditional role of professors (see Van Vught, forthcoming). The system of higher education is closer to what Clark (1964) calls the "social choice" model: decisions are "less formally and consciously determined" and result from "the interaction of interested autonomous organizations" (pp. 15-16). In this model, professors also influence decision-making at the local level through their participation in numerous committees upon which universities rely for structuring academic and administrative policies. Although the power shared by Canadian professors may appear to be less than that shared by their European counterparts, it is still an important factor in university governance. Professors' perspectives are therefore valid reference points, particularly when largely shared, for discerning the future orientations of universities. 
This paper is an attempt to answer the research question from the point of view of contingency theory analysis. Due to space limitation, it is not possible to review in detail the research conducted from the perspective of contingency theory. In the last fifteen years, the volume of research within this framework has grown very rapidly. Authors have stressed the importance of environmental variables (Snow \& Hrebiniak, 1980; Koberg, 1987). Among them, technology is often linked to organizational arrangements (Woodward, 1965; Marsh \& Mannari, 1981). But other variables also have been stressed. Thus, size (Grinyer \& Yasai-Ardekani, 1981), managerial perception of uncertainty (Kiesler \& Sproull, 1982), leadership (Fiedler, 1967) and informal relations (Leifer \& Huber, 1977) are variables found in the relevant literature.

It should be noted that contingency theory has been criticized ${ }^{1}$ because of methodological problems (Pennings, 1975; Schoonhoven, 1981, Silver, 1983), looseness of concepts employed (Fry \& Smith, 1987), the absence, in Lawrence and Lorsch's (1967) formalization of the theory, of the human actor perspective (Crozier et Friedberg 1972), and difficulties in empirically testing it (Fry \& Smith, 1987; Gresov, 1989; Ginsberg \& Venkatramass, 1985).

Ever since the first formalization of contingency theory by Lawrence and Lorsch (1967), this approach has been used extensively to account for organizational adjustments to environmental constraints, in both the public and private sectors--more in the latter than in the former. In addition, this approach is used in studies dealing with primary and secondary education (Derr and Gabarro, 1972; Crespo, Haché et Desranleau, 1985; Koberg, 1987) and at the post-secondary level (Cameron, Kim and Whetten, 1987; Cameron, 1983).

In earlier utilizations of the approach, authors tried to stick to the specific conceptual categories of Lawrence and Lorsch's (1967) formalization, i.e., differentiation and integration. Later, utilizations conceive contingency theory as a global interpretative model to account for organizational adjustments without necessarily embodying Lawrence and Lorsch's formalization. Drazin and Van de Ven (1985) have comprehensively discussed the evolution of contingency theory. In their view, there are three basic forms of contingency theory, particularly with regard to the forms of "fit" between environmental constraints and organizational responses: selection, interaction, and systemic. The first discusses fit without reference to unit performance; the second sees performance as a result of the interaction between environment and organizational responses; the third adopts a multivariate perspective in which the notion of fit and that of equifinality in systems theory are intertwined: there are varied context characteristics or contingencies, structural alternatives and performance criteria. (See also Gresov, 1989 for the notion of "fit"). 
This paper is based on the "selection" type of contingency theory - what Fry \& Smith call "congruence" (1987). Organizational adjustments to environmental constraints or contingencies are "perceptive." Instead of focusing on actual managerial strategies or, as several authors do, on dysfunctional consequences of austerity, the paper attempts to map unit future adjustment forms from strategic actors' perspectives. These perspectives are thus considered as prospective adaptive responses to contextual constraints within the "selection" type of contingency theory, that is, without consideration of their performance outcomes. Since perceptions, as part of the internal environment of organizations, play an important role in decision making, professors's views on the future structuring and functioning of universities are key elements in understanding university adaptative patterns.

Contingency theory provides a rationale for choosing relevant variables. It also serves here as a heuristic device for the understanding of organizational adjustment as it points to a fit among members' opinions, attitudes and beliefs, arrangements within the internal environment of organizations and external environmental constraints. In this study, contingency (environmental) variables are external and internal. Two external contingency variables are considered: language of department and area of specialization. Size and organizational decline are two internal contingency variables. The "language of department" variable reflects the uniqueness of some Canadian systems of higher education,and particularly that of Québec: the distinction between francophone and anglophone universities. The area of specialization reflects conditions of the external environment inasmuch as market conditions and state priorities impinge on the development of certain areas. Size is introduced as an internal contingency variable because of its already noted relevance in organizational studies (Glisson \& Yancey, 1980). Although organizational decline reflects external conditions, it is measured as a unit characteristic. The two external and the two internal environment variables (size and organizational decline) are expected to shape members' perspectives, i.e. professors.

Since perspectives can be influenced by the socio-demographic characteristics of respondents, the contingency model of this paper also includes as controls some commonly employed variables of this nature: sex, age, highest academic degree, and academic experience.

In sum, the interpretive analysis proposed in this paper is contingential because professors' perspectives are posited to depend on external and internal environmental conditions. These perspectives are "proxies" for future strategic decisions to be taken by universities (on strategies as responses to 
environmental conditions see Ginsberg \& Venkatraman, 1985; Govindarajan, 1988; Keim \& Zeithaml, 1986; Miles \& Snow, 1978; Baird \& Thomas, 1985). The framework of contingency theory is thus respected even if actual strategies are not considered.

Before proceeding to the next section on data and methods, and by way of introduction, it is necessary to make explicit an implicit ambiguity. This paper deals with the future of the university; however, the environmental variables (external and internal) are measured at the departmental level. Nevertheless, given the statutory powers of departments (selection of students, control of programs, hiring of professors, partial control over budgets, relations with the environment...), universities may be defined - although not completely - by an aggregation of departments. Consequently, the future of the university may be approached from the departments' characteristics and adjustment to external environmental conditions. This extrapolation is, of course, debatable for there are also adjustments to environmental conditions made by universities and these adjustments transcend a simple aggregation of departmental choices. In fact, organizational reality lies somewhere between the two poles of the university and the department. This research adopts the departments' rather than the university's points of view. Although it is arguable that departments' decisions will determine the adjustment of the university to its environment, it cannot be taken for granted. Therefore, the extrapolation implicitly made in this paper should be considered with caution. The findings of the paper should then be compared with findings from research yet to be conducted dealing with similar issues at the university level.

\section{Data and Methods}

Data were obtained from a survey on university management under conditions of austerity conducted in Québec in the fall of 1984 and the winter of 1985. The survey was addressed to a systematic sample (1/2) of regular university professors of all ranks in Québec universities. In all, 1225 professors returned a completed self-administered questionnaire. The rate of return was low (38\%). This rate was probably the highest obtainable given the political context in which the survey took place. At the time of its administration, the Québec government was engaged in a performance review of publicly funded institutions - both governmental and non-governmental. The issue of regular professors' work load being a sensitive one in this context, professors were perhaps reluctant to reply to a survey containing aspects related to this issue which might later be used against them. 
We feel, however, that the sample is accurate in spite of the low response rate. It should be noted that the size of the sample is not only rather large but it corresponds to around $20 \%$ of the targeted universe. Although the possibility of response biases always exists, we are confident that these are kept to a minimum because the final sample is representative of the entire population according to such basic criteria as sex, age, and language and area of specialization of department.

Using professors' responses as the unit of analysis, multiple regression analyses are used to account for variations in their perspectives. The three basic questions discussed above are translated into six different perspectives. For the excellence/equality question, only one perspective is considered, namely "selectivity in admissions"; for that of "market orientation," four perspectives are analysed: "protection of less viable departments," "market orientation of programs," "search for non-governmental funds" and "technological orientation"; finally, for the question of "university autonomy," only one perspective of the same wording is retained.

Six different regression equations were conducted, one for each of these perspectives. The predictor variables of the equations are: $x_{1}$ language of the department; $x_{2}$ area of specialization of the department; $x_{3}$ size of the department; and $x_{4}$ organizational decline. Control variables are: $x_{5}$ sex, $x_{6}$ age, $\mathrm{x}_{7}$ highest academic degree and $\mathrm{x}_{8}$ academic experience.

\section{Operationalization of Variables}

Predictor variables

Language of department

Area of specialization of department
Dichotomous variable:

0 : French

1: English

This variable has been operationalized in two ways: as dichotomous and as a series of dummy variables

Dichotomous:

$0=$ social sciences, humanities education and art

$1=$ health sciences, and pure and applied sciences

As dummy variables:

$\mathrm{D}_{1} \quad$ Health sciences

$\mathrm{D}_{2} \quad$ Pure and applied sciences 
Size of department

Organizational decline

Control variables

Sex

Age

Highest academic degree

Academic experience

Dependent variables

Selectivity in admissions

Protect' on of less viable departments

Search for non-governmental funds
$D_{3}$ Social sciences, humanities and education

Missing category: art

Ordinal variable indicating professors' perceptions or size of department

$$
\begin{array}{ll}
1= & \text { very small } \\
5= & \text { very large }
\end{array}
$$

Ordinal variable. Perception of change in number of professors on the department as compared to 5 years earlier

$$
\begin{aligned}
& 1=\quad \text { large decrease } \\
& 5=\quad \text { large increase }
\end{aligned}
$$

Dichotomous variable

$$
\begin{array}{ll}
0= & \text { Female } \\
1= & \text { Male }
\end{array}
$$

Continuous variable

Ordinal variable

$1=\quad$ Bachelor's

$2=\quad$ Master's

$3=\quad$ Ph.D. or equivalent

Continous variable

Number of years as regular professor (of all ranks)

Ordinal variable

Professor's opinion on the proposition:

"Despite the financial advantage of an 'open door' policy, the university must be more selective in admitting students"

$$
\begin{array}{ll}
1= & \text { completely agree } \\
4= & \text { completely disagree }
\end{array}
$$

Ordinal variable

Professor's opinion on the proposition:

"Budget cutbacks must be shared by all the departments so as to protect less viable departments"

$$
\begin{array}{ll}
\text { 1: } & \text { completely agree } \\
\text { 4: } & \text { completely disagree }
\end{array}
$$

Ordinal variable

Professor's opinion on the proposition:

"The university must seek to increase the non-governmental financing of its activities"

1: $\quad$ completely agree

4: completely disagree 
Market orientation in programming

Technological orientation

University autonomy
Ordinal variable

Professor's opinion on the proposition: "One of the priorities of the university must be to train students in professions for which there are needs in the job market"

1: completely agree

4: completely disagree

\section{Ordinal variable}

Professor's opinion on the proposition: "It is imperative that universities undertake measures to enable Québec society to catch up the lag observed in the development of high technology"

1: $\quad$ completely agree

4: completely disagree

Ordinal variable

Professor's opinion on the proposition

"Universities must adopt the government's priorities regarding the development of higher education"

1: $\quad$ completely agree

4: $\quad$ completely disagree

Table 1 presents selected parameters of the variables of the regression equations.

\section{Analysis of Data}

In order to get a clearer picture of the findings, the impact of the different contingency and control variables will be successively analysed. The results of bivariate and regression analyses will be jointly presented. Given the length of this paper, the results of the bivariate analyses will be given in abbreviated form; those of the regression analyses will be presented in table 2. Moreover, only the results of the bivariate analyses of the two most salient variables, i.e., language of the department and area of specialization of the department will be reported. For the other variables, solely the results of the regression analyses will be presented. In all cases, only the significant Beta coefficients are reported. 
Table 1

Parameters of variables of regression equations

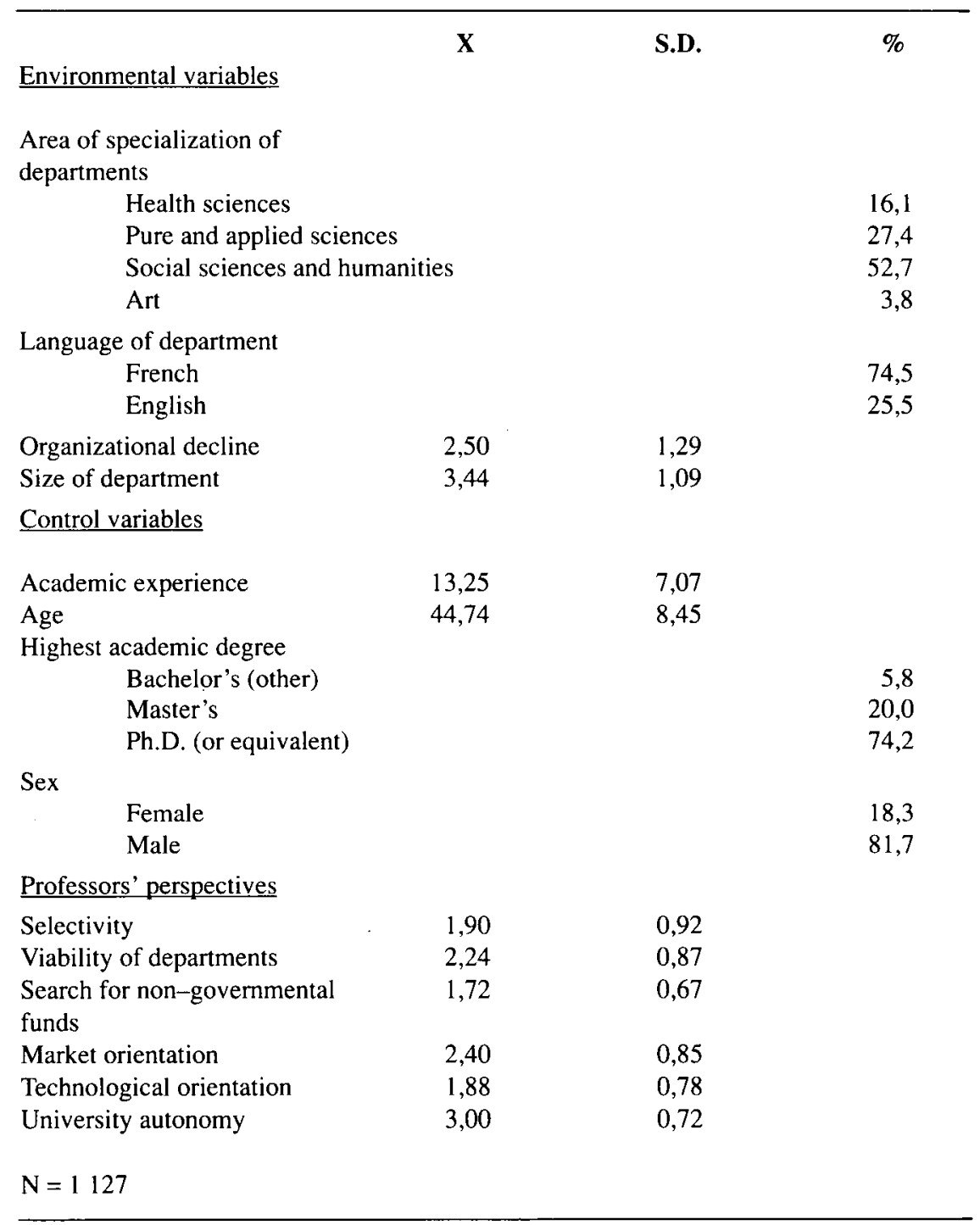


TABLE 2

Dependent Variables

\begin{tabular}{|c|c|c|c|c|c|c|}
\hline $\begin{array}{l}\text { Independent } \\
\text { Variables }\end{array}$ & $\begin{array}{l}\text { Selectivity } \\
\text { in Adminssions }\end{array}$ & $\begin{array}{l}\text { Protection of } \\
\text { Less Viable } \\
\text { Departments }\end{array}$ & $\begin{array}{l}\text { Search for } \\
\text { Non-Governmental } \\
\text { Funds }\end{array}$ & $\begin{array}{l}\text { Market } \\
\text { Orientation }\end{array}$ & $\begin{array}{l}\text { Technological } \\
\text { Orientation }\end{array}$ & $\begin{array}{l}\text { University } \\
\text { Autonomy }\end{array}$ \\
\hline $\begin{array}{l}\text { Language } \\
\text { of Department }\end{array}$ &,- 0097 &, $1164^{* * * *}$ &,- 0532 &,$- 1067^{* * *}$ &, $0836^{* *}$ &, $1906^{* * * *}$ \\
\hline $\begin{array}{l}\text { Area of Specializatio } \\
\text { of Department }\end{array}$ &,$- 1017^{* * *}$ &, $0902 * *$ &,$- 0884^{* *}$ &,$- 1176^{* * *}$ & $-.2440 * * *$ &,$- 0901^{* *}$ \\
\hline Size of Department &,- 0548 &, $1476 * * *$ &, 0084 &, 0053 &,$- 0703^{*}$ &, 0160 \\
\hline \multicolumn{7}{|l|}{ Organizational } \\
\hline Decline &, 0009 & .0410 &,- 0272 &,$- 0653^{*}$ & -.0181 &,- 0491 \\
\hline Sex &, 0193 & $.0830^{* *}$ & $-.0676^{*}$ & -.0546 &,$- 0640^{*}$ &,- 0583 \\
\hline Age & .0283 & $-.1385^{* *}$ & -.0563 & -.0558 & -.0338 & -.0338 \\
\hline \multicolumn{7}{|l|}{ Highest } \\
\hline Academic Degree &, 0168 &,- 0124 &,- 0130 &, $0786 * *$ &, $1080^{* * * *}$ &,- 0017 \\
\hline Experience &,- 0301 &, 0326 &, 0017 &, 0810 &,- 0052 &,- 0257 \\
\hline $\mathrm{R}^{2}$ &, 006 &, 057 & .014 & .034 & 084 &, 046 \\
\hline $\mathbf{N}$ & (1127) & $(1101)$ & $(1122)$ & $(1121)$ & (1113) & $(1102)$ \\
\hline 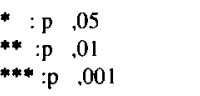 & & & & & & \\
\hline
\end{tabular}




\section{Language of departments}

There is no significant difference by language of department vis-à-vis selectivity in admission of students $(75,7 \%-77,7 \%)$. Professors of francophone departments are significantly more favourable to the protection of less viable departments than professors of anglophone departments $(66,1 \%$ versus $56,7 \%)$ $[B=, 12]$. The former professors are slightly less favourable to the search for non-governmental funds than the latter $(89,2 \%$ versus $93,8 \%)$ but the difference is not significant. It should be noted, however, that the agreement percentages are very high.

Professors of anglophone departments agree with the objective of tuning programs to market needs more than do professors of francophone departments $(63,6 \%$ versus $52,6 \%)[\beta=-, 11]$. Although the difference in opinion with regards to the technological orientation is small, proportionally more professors of francophone departments $(82,4 \%)$ agree with this objective than those of anglophone departments $(75,7 \%)[\beta=, 08]$. Finally, both groups are against a realignment on governmental priorities in higher education, but professors of anglophone departments disagree more strongly $(92,6 \%$ versus $75,1 \%)[B=$ ,19].

\section{Area of specialization of departments}

In table 2, area of specialization has been operationalized as a dichotomous variable. This variable discriminates between social sciences, humanities, education and art $(0)$ and health sciences and pure and applied sciences (1).

Some marked differences in perspectives are found among professors according to area of specialization. Pure and applied science $(83,7 \%)$ and health sciences $(76,6 \%)$ professors agree the most with a selective policy of admissions. Professors of departments of social sciences $(72,2 \%)$ and arts $(66,7 \%)$ are less prone to adopt such a policy $[B=-, 10]$. Forty-five percent of professors of departments of pure and applied sciences do not approve of the protection of less viable departments. Professors of health sciences and social sciences departments show similar percentages of disagreement (around 38\% closer to those of the latter professors). By contrast, professors of art and humanities departments strongly agree with this policy $(84 \%)[B=, 09]$. Although a very large proportion of professors of all departments (between $88 \%$ and 95\%) approve the search for non-governmental funds, professors of health sciences and pure and applied sciences departments agree more strongly $[B=$ $-, 09]$. 
As for the market orientation in programming, there is a net cleavage between professors of departments of health sciences and pure and applied sciences on the one hand, $(62,4 \%$ and $63,0 \%$ respectively) and, on the other hand, professors of departments of social sciences and professors of departments of art and the humanities $(54,2 \%$ and $33,7 \%$ respectively) $[B=-, 12]$. The same cleavage appears with regard to the closing of the technological gap of Québec society. Professors of social sciences and humanities, and art departments, are less inclined to agree with this objective-although a comfortable majority $(71,8 \%)$ accept it - than professors from health sciences and pure and applied sciences departments $(90,9 \%)[B=-, 24]$.

A large majority of professors, irrespective of the area of specialization of the department, disagree with an alignment on government policies in higher education. Professors of departments of social sciences, humanities and art disagree more strongly $(81,8 \%)$ than professors of departments of health sciences and pure and applied sciences $(75,4 \%)[B=-, 09]$.

\section{Size}

For this variable, significant differences are found in only two professors' perspectives: maintenance of less viable departments and technological orientation.

Professors of larger departments are more against maintaining the less viable departments $[B=, 15]$ than professors of smaller departments. Neither do the former think that universities should have as top priority the reduction of the technological gap of Québec society [ $\beta=-, 07]$.

\section{Decline}

This variable influences only one perspective: the market orientation of higher education programming. Professors of declining departments, as compared with professors of stable or growing departments, do not agree with such an orientation $[\beta=-, 07]$.

\section{Control variables}

Academic degree and particularly sex are salient among the control variables. The higher the professors' academic degree, the less they agree with a market orientation $[\beta=, 08]$ and with pursuing a policy of reduction of the technological $\operatorname{gap}[\beta=, 11]$. 
Female professors agree more than their male counterparts with maintaining less viable departments $[\beta=, 08]$. They disagree with a policy of searching for non-governmental funds $[B=-, 07]$ and do not believe that it is imperative that universities undertake measures to reduce the technological gap of Québec society $[B=-, 06]$.

It should be noted that age influences only one perspective, namely the maintenance of less viable departments, older professors favouring such an objective. Academic experience is not related to any interpretation of the perspectives analysed.

External contingency variables (language and area of specialization of department) have been proved to influence professors' perspectives. This is not the case with internal contingency variables (size and organizational decline), especially with regards to the decline variable. Area of specialization has a significant impact on all six perspectives; language of department is related to four of the six perspectives. With the exception of sex, the control variables do not appear to have a constant effect on professors' perspectives.

When the categorical variable "area of specialization" is transformed into dummy variables, some differences vis-à-vis the results of the previous model appear. These differences do not, however, alter the basic results presented earlier. In the new model, "language of department" influences the same four perspectives in comparable ways. The "area of specialization of the department" variable retains its same sign and strength but for only four out of the six previously influenced perspectives. Area of specialization does not retain a significant effect on the variables "search for non governmental funds" and "university autonomy." The control variables do not, in general, have significant effects on the dependent variables.

The introduction of dummy variables has slightly increased the respective explained variances. On only one occasion, however, does the percentage increase exceed $1 \%$ ( - for the "technological orientation" perspective: from $8,4 \%$ to $10,6 \%$ ).

\section{Discussion of Findings}

In this section, some of the relevant findings of this research are discussed. The findings deal successively with the impact of language and area of specialization of departments, with the relevance of the decline variable in organizational analysis and, finally, with the observed variations according to sex of respondent - the most salient amongst the control variables. 


\section{The impact of language of department}

The language cleavage is an important factor in the Canadian context. For the majority of perspectives, the anglo-franco split is evident. Anglophones seem to be more open to the non-academic world, more efficiency minded and more jealous of university autonomy. Anglophone universities on the North American continent have a long history of cooperation with the private sector. Numerous universities in Canada and the U.S. were founded with the aid of large private donations.

Moreover, anglophones in Québec, historically, have been suspicious of Québec governments led by the francophone majority. This suspicion may tend to pervade all realms of activity, including the university. This is not the sole cause, of course, since the relatively high funding levels from the private sector help to maintain a more independent stand vis-à-vis governmental priorities in higher education. Market orientation and the weaker endorsement of a policy of maintaining less viable departments are additional evidence of a pragmatic attitude more consonant with the anglophone organizational culture.

\section{The impact of departmental specialization}

The differences in perspectives according to areas of specialization of department need not be discussed at length: they translate established orientations and actual organizational characteristics of departments of pure and applied sciences versus departments of social sciences and humanities. Since, on the whole, the former departments have not suffered greatly from declining conditions, they are not much in favour of policies that might restrict the overall level of resources because of the costs of maintaining less productive departments. Also, pure and applied sciences departments have a much greater market value for, and greater congruence with, industry than other departments in academe. Such departments are more successful in obtaining financial resources from the private sector which, in turn, enhances their independence vis-à-vis governmental policies for higher education.

\section{The decline hypothesis}

The data of this paper question the hypothesis of the impact of decline. When used in conjunction with other classical structural variables (e.g., size, area of specialization of unit), organizational decline proved to be irrelevant. This 
finding ought to be considered when evaluating the effects of measures of organizational decline employed in analyses devoid of other structural variables. Part of the effect of missing structural variables may well be picked up by the decline variable, thus inducing the attribution to this latter variable of spurious effects. $^{2}$

\section{Gender as control variable}

As already mentioned, female professors were favourable to the maintenance of less viable departments, were not much inclined to search for non-governmental funds and favoured a technological orientation to a lesser degree than male professors. It is difficult to disentangle what is gender specific in this difference because female professors are over-represented in more vulnerable departments such as art departments (32\%) and under represented in pure and applied science departments $(8,2 \%)$. The proportion of females in the sample is $18,3 \%$.

\section{Concluding Remarks}

This research has shown that environmental characteristics may shape professors' perspectives on issues related to the future of the university. External environmental contingency factors were shown to be more relevant in accounting for differences in professors' perspectives than internal ones. It should be noted, however, that the main regression model used here, although adequate in all instances, is weak. The percentages of explained variances are low. They range from less than 1 percent (selectivity) to $8,4 \%$ (technological orientation). What is intriguing is that socio-demographic and professional variables do not explain variations in perceptions. But, even these variations are not very large. ${ }^{3}$ They may thus be seen as "modulations" of the same theme. In fact, in all cases a clear majority - in some cases, an overwhelming majority agree or disagree with the stated perspective. It may be recalled that more than two thirds of respondents $(76,2 \%)$ advocate greater selectivity in university admissions. A majority of respondents $(55,4 \%)$ agree with a market orientation in university training. Around $90 \%$ of respondents would like their universities to search for non-governmental funds. Almost two thirds $(63,7 \%)$ favour the protection of less viable departments. According to a strong majority of respondents $(80,7 \%)$, universities should strive to reduce the technological gap of Québec society. Finally, $80 \%$ of professors would favour greater autonomy with respect to governmental priorities in higher education. 
The congruence of professors' perspectives is perhaps the most relevant factor since it suggests a growing consensus on the future of the university. Differences do exist between anglophone and francophone departments, and between academic sectors, but the general trend is very similar in spite of these differences. Future research should perhaps look for determinants of congruence in professors' perspectives. Some lines of research merit further exploration, such as the societal disenchantment with the quality of post-secondary training, the redefinition of boundaries between types of post-secondary education and the drive for conquest of world markets and the consequent bias towards technological goals.

Before concluding, two policy implications of some of the results of this research merit discussion. The selectivity "bias" may be a response to pressures towards excellence, but it may also hinder the democratization of higher education. Selectivity is a major issue in France since the government is trying to increase the number of "bacheliers" (secondary leaving certificate-holders) to $80 \%$ of their age group. Given the general lack of student places in France, this policy, if successful, will exert tremendous constraints on the system. No one knows for sure what Québec's choice will be: will it be an open-door policy or an elitist one? The government of Québec has recently raised tuition fees to help the universities stabilize their budgets. Even if this policy may restrict access to university, it is clearly not an elitist option - even though it may be considered as having a social class bias. Government officials cite the American example as proof of the small effect of high tuition fees on students' participation in post-secondary education.

A selectivity policy may result in a diversification of post-secondary education. Governments perhaps may wish to strike a balance between democratization and excellence through a diversification of the higher education system. However, this is another matter that takes us rather far from our present discussion. What seems clear is that, at least as far as Québec is concerned, a selectivity policy in higher education would have found no strong opposition among university professors in the late eighties.

Another policy implication stems from the data. Professors are strongly $(90 \%)$ in favour of the search for alternative sources of funding. On account of the shrinking of resources in the eighties, universities have resorted to increasing cooperation with the private sector. This strategy seems to retain a wide consensus among university professors. But this openness to the private sector may become somewhat problematic since a great majority of professors (80\%) also favours university autonomy. The question then arises as to how local administrations can, at the same time, be supported by the private sector, 
keep control over their own goals and protect academic freedom. The data of this paper merely point to the existence of a possible mismatch between the constraints stemming from private funding and the legitimate aspirations of the universities. Data gathered for other purposes tend to show that autonomy is conditional on diversification of sources of income. When funding is spread among a variety of firms and donors, university administrators are better able to resist pressures from the environment (Crespo, 1990).

Openness to the socio-economic environment does not seem to encounter strong resistance among professors. This may, however, be a "wait and see" attitude: professors would first want to know who the beneficiaries of university-industry relations are before making up their minds. Do university-industry relations benefit the entire academic community or only some specific sectors within it? This question must be answered before concluding that the strong agreement revealed by the survey is in fact a stable attitude among professors.

The other side of the coin regarding the search for non-governmental funds is the equally strong agreement among professors on achieving greater autonomy from governmental priorities in higher education. The Québec university system is, for the most part, private, i.e., its governance at the local level depends on an independent Board of Trustees. However, governmental sources account for over $80 \%$ of all financing. Thus, the Québec government exerts pressures on universities through its budget allocations and its decisions on the financing of university development. In the recent past, new students were differentially financed according to field of specialization, universities receiving proportionally more funding for new students enrolled in programs contributing to the "virage technologique" (technological shift).

In spite of relative university autonomy - objectively greater than that of several societies - professors aspire to a broader realm of decision-making in university affairs. Here perhaps is to be found a meaning of what constitutes the university: a generous vision of intellectual work and creativity irrespective of domain of knowledge.

Does this mean that university professors in Québec are insensitive to market constraints or governmental policies of economic development? The answer is certainly no since four out of five professors think that universities should contribute to the reduction of the technological gap of Québec society. Moreover, at least a majority of them recognize the need for some market orientation in university programming. 
The data provide no clue to the solution of the dilemma between greater autonomy, and consequently lesser alignment on governmental priorities, and market orientation and the aim of reducing the technological gap of Québec society. What appears to be clear is that there is room for negotiation. The drive for greater autonomy does not evolve in a vacuum: strategic alliances can be achieved when higher order needs or institutional survival are at stake.

As a final comment, despite the low level of explained variances and the use of contingency theory as a heuristic device, the findings of this paper give some support to the theory in a little-researched area. A review of the relevant literature shows that most of the studies within the contingency framework have tackled the question of "fit" between environment and organization from the point of view of either structure, organizational processes or performance. Only a few have addressed this question from the point of view of members and socio-psychological processes and, when this was the case, the emphasis was laid on issues of satisfaction and performance. Thus, it is hoped that this paper may contribute to widening the field of analysis.

\section{Notes}

This short résumé of relevant variables of research based on contingency theory and of problems of contingency theory as an analytical framework is taken from Ouardi's doctoral dissertation (Ouardi, 1987).

2 The effects of language of department and area of specialization are orthogonal and independent from the other structural variables (size and decline). Regression analyses involving multiplicative variables to test for interaction between these variables did not increase the explained variances, nor did the newly created variables have significant regression coefficients. In these regression analyses, the decline variable had no significant impact on the perspectives, either. This is particularly relevant since the decline variable, either alone or with multiplicative variables, was not significant.

3 When considered as ordinal variables, perceptions show variability as may be seen in Table 1. However, the measurement of perspectives through a reduced range of discrete categories may enhance the size of the standard deviation. Given the strong general agreement or disagreement on perspectives, it may be hypothesized that the standard deviation would be smaller if the perspectives were measured in continuous form. 


\section{References}

Astin, Alexander W. (1985). Achieving educational excellence. San Francisco: JosseyBass.

Ashworth, John M. (1985). Universities and industry: National and institutional perspectives. Oxford Review of Education, $11,235-243$.

Avveduto, S., et Silvani, A. (1988). Les relations université-industrie: le rôle potentiel des parcs scientifiques en Italie. Revue internationale de gestion des établissements d'enseignementt supérieur, 12 (2), 192-204.

Baird, I.S., and Thomas, H. (1985). Toward a contingency model of strategic risk taking. Academy of Management Review, 10, 230-243.

Bélanger, C.H. (1988). Les parcs scientifiques canadiens. Revue intenationale de gestion des établissements d'enseignement supérieur, 12 (2), 205-214.

Berchem, Theodor. (1985). University autonomy: Illusion or reality?. Oxford Review of Education, 1I, 245-254.

Cameron, Kim S., Kim, Myung U., and Whetten, David A. (1987). Organizational effects of decline and turbulence. Administrative Science Quarterly, 32, 222-240.

Cameron, Kim S., Whetten, David A., and Kim, Myung U. (1987). Organizational dysfunctions of decline. Academy of Management Journal, 30, 126-138.

Cerych, Ladislav. (1985). Collaboration between higher education and industry: An overview. European Journal of Education, 20, 7-18.

Clark, Burton R. (1964). Social trends and educational organization. Paper presented at 59th Annual Meeting of the American Sociological Association, Montréal, September.

Clark, Burton R. (1977). The changing relations between higher education and government; save perspectives from abroad. Yale Higher Education Research Group Working Paper, New Haven, Conn.: Yale University, Institute for Social and Policy Studies.

Clark, Burton R. (1983). Governing the higher education system. In Shattock, Michael, The structure and governance of higher education. Guilford, Surrey: Society for Research into Higher Education, 19-45.

Crespo, Manuel, with the collaboration of Ouardi, Mohammadine. (1989). The management of austerity in higher education: An international comparison. Higher Education, 18, 373-395.

Crespo, Manuel. (1990). Les relations universitélindustrie en France et en République fédérale allemande. Paper presented at the 14th Congress of the Comparative Education Society in Europe. Madrid, 2-7 July.

Crespo, Manuel, Haché, Jean, et Desranleau, Claude. (1985). Dimensions rurales-urbaines de la gestion scolaire en contexte de décroissance des clientèles et des compressions budgétaires. Revue Internationale de Pédagogie, 31 , 59-84.

Crozier, M., et Friedberg, E. (1977). L'acteur et le système. Paris: Seuil. 
Derr, C.B., and Gabarro, J.J. (1972). An organizational contingency theory for education. Educational Administration Quarterly, 8, 26-43.

Drazin, Robert, and Van de Ven, Andrew H. (1985). Alternative forms of fit in contingency theory. Administrative Science Quarterly, 30, 514-539.

Fiedler, F.E. (1967). A theory of leadership effectiveness. New York : Free Press.

Forum entreprises-universités (1987). Du mécénat au partenariat. Le soutien des entreprises aux universités. Montréal.

Forum entreprises-universités (1985). Investir plus sagement. Collaboration entreprises-universités en recherche et développement. Montréal.

Forum entreprises-universités (1984). Ensemble vers l'avenir. La collaboration entreprise-université au Canada. Montréal.

Fry, Louis W., and Smith, D.A. (1987). Congruence, contingency, and theory building. Academy of Management Review, 12, 117-132.

Fulton, Oliver. (1988). Elite survivals? Entry 'standards' and procedures for higher education admissions. Studies' in Higher Education, 13, 15-25.

Ginsberg, A., and Venkatraman, N. (1985). Contingency perspectives of organizational strategy: A critical review of the empirical research. Academy of Management Review, 10, 421-434.

Glisson, C.A., and Yancey, M.E. (1980). Productivity and efficiency in human service organizations as related to structure, size and age. Academy of Management Journal, 23, 21-37.

Govindarajan, V. (1988). A contingency approach to strategy implementation at the business - unit level: Integrating administrative mechanisms with strategy. Academy of Management Journal, 31, 828-853.

Gresov, Christopher. (1989). Exploring fit and misfit with multiple contingencies. Administrative Science Quarterly, 34, 431-453.

Gringer, P., and Yasai-Ardekani, M. (1981). Strategy, structure, size and bureaucracy. Academy of Management Journal, 24, 471-496.

Hardy, Cynthia. (1984). The management of university cutbacks: Practice, planning and participation. Canadian Journal of Higher Education, 14 (1), 59-69.

Halls, W.D. (1985). Universities, the polity and the market place. Oxford Review of Education, 11, 263-269.

Jackson, G.A. (1979). Community colleges on budget reduction. Stanford: Stanford University, California Institute for Research on Educational Finance and Governance.

Keim, G.D., and Zeithaml, C.P. (1986). Corporate political strategy and legislative decision making: A review and contingency approach. Academy of Management Review, 11, 828-843.

Kiesler, S., and Sproull (1982). Managerial response to changing environment, perspectives on problem sensing from social cognition. Administrative Science Quarterly, 27, 548-570. 
Koberg, Christine S. (1987). Resource scarcity, environmental uncertainty, and adaptive organizational behavior. Academy of Management Journal, 30, 798-807.

Laplante, Laurent. (1988). L'université. Questions et défis. Québec: Institut québécois de recherche sur la culture.

Lesourne, Jacques. (1989). L'avenir des sociétés industrielles et l'enseignement supérieur. Gestion de l'enseignement supérieur, l (3), 317-332.

Levin, Benjamin, and Sullivan, Nancy. (1988). Government and universities. The Canadian Journal of Higher Education, 18, 1-5.

Lawrence, P., and Lorsch, J. (1967). Organization and environment. Cambridge: Harvard University Press.

Leclerc, Michel. (1988). Le financement corporatif de la recherche universitaire. La revue canadienne de l'enseignement supérieur, 18, 13-29.

Leifer, R., and Huber, G.P. (1977). Relations among perceived environmental uncertainty, organization structure, and boundary spanning behavior. Administrative Science Quarterly, 22, 235-247.

March, J.G., and Olsen, J.P. (1975). Choice situations in loosely coupled worlds. Unpublished paper, Stanford University.

Marsch, R.M., and Mannari, H. (1981). Technology and size as determinants of the organizational structure of Japanese factories. Administrative Science Quarterly, 26 (1), 33-57.

Marsch, R.M., and Mannari, H. (1981). Technology and size as determinants of organizational structure of Japaneese factories. Administrative Science Quarterly, 26 (1981), 33-57.

McKinnon, K.R. (1988). Higher education and industry. Higher Education Quarterly, 42, 179-192.

Miles, R.E., and Snow, C.C. (1978). Organizational strategy, structure, and process. New York: Mc Graw Hill.

Miller, Roger, and Côté, Marcel. (1987). Growing the next Silicon Valley. A guideline for successful regional planning. Lexington, Massachusetts: Lexington Books.

Moodie, Graeme C. (1988). The debates about higher education quality in Britain and the U.S.A. Studies in Higher Education, 13, 5-13.

Muller, Thomas E., and Sepehri, Vera A. (1988). Corporate support of higher education: Trends in Canada and the United States. Research in Higher Education, 28, 160-179.

National Institute of Education. (1984). Involvement in learning: Realizing the potential of American higher education. Report of the Study Group on the Conditions of Excellence in American Higher Education. Washington, D.C.: NIE/V.S. Department of Education.

OECD (1987). Quel avenir pour les universités? Paris : OECD.

Ouardi, Mohammadine. (1987).Choix de stratégies en période de décroissance: Analyse des conséquences. Unpublished doctoral dissertation. Montréal: Université de Montréal. 
Pennings, J.M. (1975). The relevance of the structural-contingency model for organizational effectiveness. Administrative Science Quarterly, 20, 393-410.

Pennsylvania State University. (1980). A perspective on the 80's: Agenda for action for the Pennsylvania State University. Pennsylvania State University.

Powers, David, and Powers, Mary F. (1988). Higher education in partnership with industry, opportunities and strategies for training, research and economic development.. New York: Jossey Bass Publishers.

Salancik, Gerald R. (1975). Notes on loose coupling : Linking intentions to actions. Unpublished paper, Urbana-Champaign: University of Illinois.

Scheidt, O.H. (1978). Institutional response to forced budget reductions. Paper presented at the Conference The Taxpayer Revolt - Where do we go from here? Dallas, Texas.

Schoonhoven, C.B. (1981). Problems with contingency theory : Testing theory assumptions hidden within the language of contingency. Administrative Science Quarterly, 26, 349-377.

Science Council of Canada. (1988). Winning in a world economy. University-industry interaction and economic renewal in Canada. Report 39. Ottawa: Science Council of Canada.

Shattock, Michael, and Berdhal, Robert. (1984). The British University Grants Committee 1919-1983: Changing relationships with government and the university. Higher Education, 13 (5) : 471-499.

Shore, Valerie. (1985). UBC President's Resignation. University Affairs, April, p. 7.

Silver, P. (1983). Educational Administration: Theoretical perspectives on practices and research. New York : Harper \& Row.

Sizer, John. (1988). In search of excellence - performance assessment in the United Kingdom. Higher Education Quarterly, 42, 152-161.

Slaughter, Sheila. (1988). Academic freedom and the state, reflections on the uses of knowledge. Journal of Higher Education, 59, 241-262.

Smith, D.K. (1980). Preparing for a decade of enrollment decline: The experience of the University of Wisconsin system. Conference paper, Southern Regional Board, Atlanta, Georgia.

Snow, C.C., and Hrebiniak, L.C. (1980). Industry differences in environmental uncertainty and organizational characteristics related to uncertainty. Academy of Management Journal, 23 (4), 750-759.

Stankiewicz, R. (1986). Academics and entrepreneurs. Developing university-industry relations. New York: St-Martin's Press Inc.

Theis, A., Groumann, W., and Oppermann, Th. (eds.). (1986).Wissenstransfer zwischen universität und wirschaft. Neue formen der kooperation in westeuropa. Baden-Baden: Nomos Verlagsgesellschaft.

Trow, Martin. (1987). The national reports on higher education: A skeptical view. Educational Policy, 1, 411-427.

Van Vught, Frans. (1992). Governance and higher education in Europe. Canadian and International Education (forthcoming). 
Varrin, R., and Kubich, D. (1985). Guidelines for industry - sponsored research at universities. Science, 227, 385-388.

Volkwein, Fredericks J. (1986). Campus autonomy and its relationship to measures of university quality. Journal of Higher Education, 57, 510-528.

Volkwein, Fredericks. (1984). Responding to financial retrenchment: Lessons from the Albany experience. Journal of Higher Education, 55 (3), 389-401.

Wasser, Henry. (1989). Changing relations between universities and research policy and industry: From the elite traditional to the popular entrepreneurial. History of European Ideas, Vol. II; 653-659.

Weick, Karl E. (1976). Educational organizations as loosely coupled systems. Administrative Science Quarterly, 21, 1-19.

Woodward, J. (1965). Industrial Organizations. London: Oxford University Press. 